\title{
Critical Difference of Some Bovine Haematological Parameters
}

\author{
By A. L. Jensen, H. Houe, and C. G. Nielsen \\ Department of Clinical Studies, Royal Veterinary and Agricultural University, Frederiksberg, Denmark.
}

\begin{abstract}
Jensen, A. L., H. Houe and C. G. Nielsen: Critical difference of some bovine haematological parameters. Acta vet. scand. 1992,33, 211-217. - The purpose of the present study was to calculate the critical difference between 2 analytical results for the red blood cell count (RBC), the white blood cell count (WBC), the haemoglobin concentration $(\mathrm{Hb})$, and the haematocrit (PCV) in blood from Red Danish Dairy cows. The critical difference can help to judge whether the difference between 2 consecutive analytical results from the same animal may be safely ascribed to natural variation or not.

To calculate the critical differences, blood samples from 20 clinically healthy lactating cows were collected once daily for 5 consecutive days. The total variance of the analytical results was divided into the component of variance between cows $\left(\mathrm{S}_{\text {Inter }}^{2}\right)$, the component of variance for days within cows $\left(\mathrm{S}_{\text {Intra }}^{2}\right)$, and the component of variance for measurements $\left(\mathrm{S}_{\mathrm{Anal}}^{2}\right)$ using nested analysis of variance. The critical difference was then calculated from $S_{\text {Intra }}^{2}$ and $S_{\text {Anal }}^{2}$ as $0.61 \times 10^{12} / 1$ for RBC, $2.2 \times 10^{9} / 1$ for WBC, $0.79 \mathrm{mmol} / \mathrm{l}$ for $\mathrm{Hb}$, and 0.07 for PCV.

The critical differences may be used as guidelines to indicate potentially important changes in the parameters. However, the analytical results should not be assessed by the critical differences alone, but should also be compared to the corresponding reference intervals.
\end{abstract}

repeated measurements; variation.

\section{Introduction}

In veterinary medicine, the most commonly used method of assessment of results from haematological and clinical chemical analyses is probably the transverse assessment, i.e. comparing the result to a corresponding reference interval obtained from a representative reference population. A frequent finding is, however, that the range of analytical results from animals with diseases overlap the range of analytical results from the reference population, and therefore, cutoff values optimal to the intended use of the diagnostic test have to be determined. Presumably, the scope of a haematological or clinical chemical analysis is in most cases to observe whether the current measurement is part of a trend toward another physiological state in the particular animal. It may therefore be suggested that the animal could be used as its own reference by comparing analytical results from samples obtained serially at intervals appropriate to the experimental influence or to the expected rate of development of disease or improvement. For that purpose, the critical difference $\left(d_{k}\right)$ has been developed as a tool to follow the course of 1 parameter in 1 individual in consecutive measure- 
ments (Stamm 1982, Costongs et al. 1985). The critical difference is derived from the following theoretical assumptions: The standard deviation of the difference between 2 independent, random variables with the same expected mean value and the same standard deviation $(\sigma)$ is $\sqrt{2} \cdot \sigma$. The probability that the difference between the 2 variables is less than or equal to $2 \cdot \sqrt{2} \cdot \sigma$ is about $95 \%$ and if the difference between 2 results is greater than $2 \cdot \sqrt{2} \cdot \sigma$, the results can be regarded as being different (Stamm 1982). The implication of this is, that if the difference between 2 consecutive results is less than the critical difference, then the difference may safely be ascribed to natural variation. If the difference between the 2 consecutive measurements is greater than the critical difference, then factors other than natural variation may be responsible for the difference.

In the clinical situation, the interest may primarily be on changes in analytical results occurring within an interval of 2 or 3 days or a week in order to follow the progress or course of disease or the response to treatment. The present study was therefore conducted to establish the critical difference for
4 routinely used bovine haematological parameters on a day-to-day basis.

\section{Materials and methods \\ Sample collection}

Blood samples for haematological analysis were collected from the tail vein once daily between 07.00 and 08.00 a.m. just after morning milking of 20 clinically healthy lactating Red Danish dairy cows at a private farm (10 cows in the first parity, 3 cows in the second parity, and 7 cows in the third parity). The blood samples were collected in vacutainers ${ }^{\circledR}$ (Becton-Dickinson) containing $0.12 \mathrm{ml}$ of $0.34 \mathrm{~mol} / 1$ tripotassium ethylene diaminotetraacetate $\left(\mathrm{K}_{3}\right.$ EDTA). Care was taken not to exite the cows during venipuncture in order to reduce any effect on the parameters investigated from stress caused by handling.

\section{Analytical procedures}

Within $3 \mathrm{~h}$ after collection of the blood, haematological parameters were determined in the same run. Haematological analyses included total red blood cell count (RBC), total white blood cell count (WBC), haemoglobin concentration $(\mathrm{Hb})$, and haematocrit (PCV).

Table 1. The Critical Difference $\left(d_{k}\right)$ in Absolute Values Calculated from the Component of Variance between Cows $\left(S_{\text {Inter }}^{2}\right)$, the Component of Variance for Days within Cows $\left(S^{2}{ }_{\text {Intra }}\right)$, and the Component of Variance for Measurements $\left(\mathrm{S}^{2}\right.$ Anal $)$ for 4 Haematological Parameters of the Red Danish Dairy Cow.

\begin{tabular}{llllll}
\hline Parameter & Unit & $\mathrm{S}_{\text {Inter }}^{2}$ & $\mathrm{~S}_{\text {Intra }}^{2}$ & $\mathrm{~S}_{\text {Anal }}$ & $\mathrm{d}_{\mathrm{k}}$ \\
\hline $\begin{array}{l}\text { Red blood } \\
\text { cell count }\end{array}$ & $\left(\times 10^{12} / \mathrm{l}\right)$ & 0.3691 & 0.0438 & 0.0027 & 0.61 \\
$\begin{array}{l}\text { White blood } \\
\text { cell count }\end{array}$ & $\left(\times 10^{9} / \mathrm{l}\right)$ & 4.5809 & 0.6208 & 0.0066 & 2.2 \\
$\begin{array}{l}\text { Haemoglobin } \\
\text { concentration }\end{array}$ & $(\mathrm{mmol} / \mathrm{l})$ & 0.5789 & 0.0626 & 0.0144 & 0.79 \\
\begin{tabular}{l} 
Haematocrit \\
\hline
\end{tabular} & 0.000638 & 0.000433 & 0.000115 & 0.07 \\
\hline
\end{tabular}


$\mathrm{RBC}, \mathrm{WBC}$, and $\mathrm{Hb}$ were determined in the model S560 Coulter Counter. PCV was determined in microhaematocrit capillary tubes in a microhaematocrit centrifuge (Haemofuge A, Heraeus Sepatech). All analyses were done in duplicate.

\section{Statistical analysis}

The entire data set on each parameter was
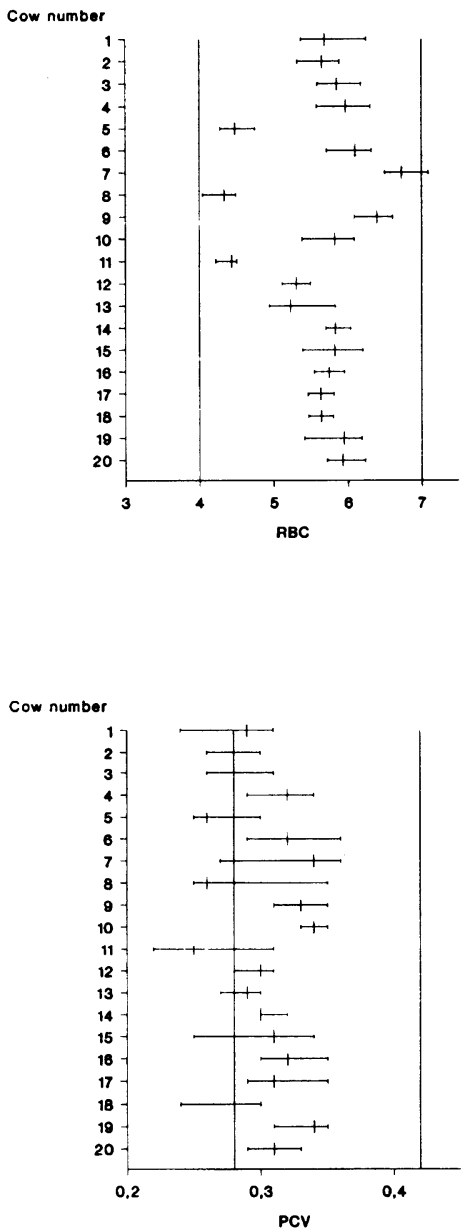

evaluated for approximate normality of distribution using the Shapiro-Wilk statistic. Further, the entire set of results for each parameter was evaluated for statistically significant changes in concentration with time using regression analysis.

To illustrate the dispersion of the variation around the mean value of each cow against the reference interval, the mean values and
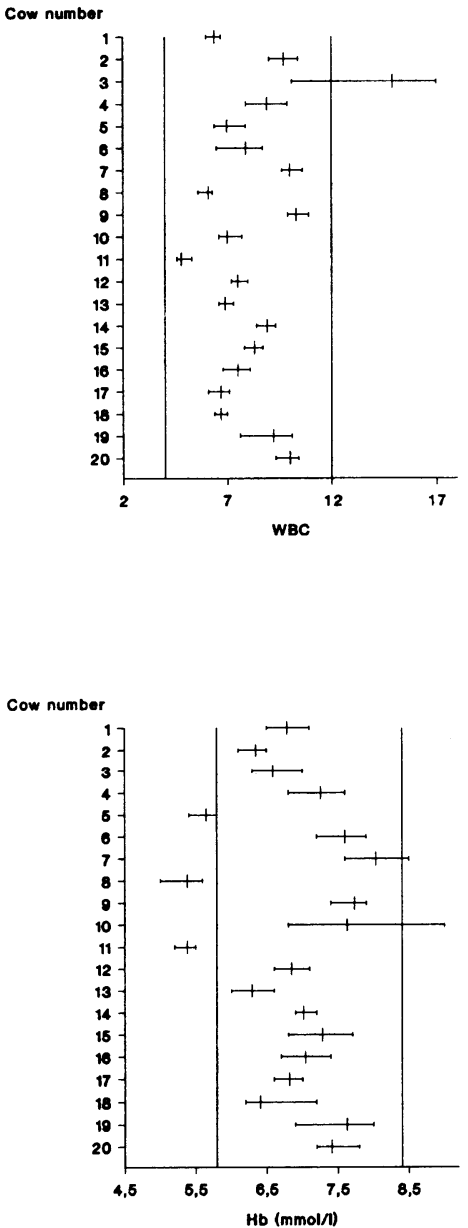

Figure 1. Mean values and absolute ranges for the red blood cell count (RBC), the white blood cell count (WBC), the haemoglobin concentration (Hb), and the haematocrit (PCV) measured once daily for 5 consecutive days in 20 clinically healthy lactating Red Danish Dairy cows. The vertical solid lines represent the reference interval $\left(4.00-7.00 \times 10^{12} / 1\right.$ for RBC, $4.0-12.0 \times 10^{9} / 1$ for WBC, $5.8-8.4 \mathrm{mmol} / \mathrm{l}$ for $\mathrm{Hb}$, and $0.28-$ 0.42 for PCV). 
absolute ranges for $\mathrm{RBC}, \mathrm{WBC}, \mathrm{Hb}$, and PCV of the 20 cows are displayed in Fig. 1.

The critical difference $\left(d_{k}\right)$ of each parameter was calculated as previously described (Jensen et al. 1992) using nested analysis of variance to divide the total variance into the component of variance between cows $\left(\mathrm{S}_{\text {Inter }}^{2}\right)$, the component of variance for days within cows $\left(\mathrm{S}^{2}{ }_{\text {Intra }}\right)$, and the component of variance for measurements $\left(\mathrm{S}^{2}{ }_{\mathrm{Anal}}\right)$. Because the variance in the present study predominantly depended on $\mathrm{S}_{\text {Inter, }}^{2} \mathrm{~S}_{\text {Intra }}^{2}$, and $\mathrm{S}^{2}$ Anal, the component of variance due to other factors $\left(\mathrm{S}^{2}\right.$ Others $)$ being minimized by the experimental design, the estimate of the standard deviation could be calculated from the $S^{2}{ }_{\text {Intra }}$ and $S^{2}$ Anal, and thus the critical difference could be calculated in absolute value as $\mathrm{d}_{\mathrm{k}}=2 \cdot \sqrt{2\left(S_{\text {Intra }}^{2}+S_{\text {Anal }}^{2}\right)}$.

The F-test described by Snedecor \& Cochran (1967) was used to observe whether the parameters varied from day to day (i.e. $\mathrm{S}^{2}$ Intra greater than 0 ) and from cow to cow (i.e. $S_{\text {Inter }}^{2}$ greater than 0 ). Briefly, the $F$ value for variation from day to day was calculated as the mean square of $S^{2}{ }_{\text {Intra }}$ divided by the mean square of $\mathrm{S}^{2}$ Anal , and the $\mathrm{F}$ value for variation between cows was calculated as the mean square of $\mathrm{S}_{\text {Inter }}$ divided by the mean square of $S_{\text {Intra }}^{2}$

\section{Results}

The Shapiro-Wilk statistic indicated that all raw data were distributed in a Gaussian manner.

The regression analysis showed no statistically significant trends for changes in the concentration of the parameters with time as none of the slopes of the regression lines were significantly different from 0 .

Fig. 1 shows the mean values and absolute ranges for $\mathrm{RBC}, \mathrm{WBC}, \mathrm{Hb}$, and $\mathrm{PCV}$ of each of the 20 clinically healthy lactating cows. Most cows had mean values within the reference intervals of this laboratory. For all parameters, the mean value of the individual cow differed considerably between cows and the variation of the results around the mean value was smaller than the dispersion of the corresponding reference interval.

Table 1 summarizes the conponent of variance between cows $\left(\mathrm{S}_{\text {Inter }}^{2}\right)$, the component of variance for days within cows $\left(\mathrm{S}_{\text {Intra }}^{2}\right)$, the component of variance for measurements $\left(S^{2}{ }_{\text {Anal }}\right)$, and the critical difference $\left(d_{k}\right)$ in absolute values for each of the 4 haematological parameters examined in the present study. Finally, the parameters evidently varied both from day to day and from cow to cow since $S_{\text {Inter }}^{2}$ as well as $S_{\text {Intra }}^{2}$ were significantly greater than 0 for each parameter (data not shown).

\section{Discussion}

Interpretation of analytical results from haematological and clinical chemical analysis in veterinary medicine is commonly based on the analytical result being compared to a corresponding reference interval obtained from a representative reference population. However, as illustrated in Fig. 1, the variation around the mean value of each animal may be smaller than the dispersion of the reference interval. It is therefore possible that a single animal with a disease affecting a given parameter could have an analytical result outside its own reference interval, but within the corresponding population-based reference interval at the time of collecting the blood sample. For the haematological parameters of this study, this possibility is further evidenced if the statements of Harris on the degree of individuality (the square-root of the ratio of $\mathrm{S}_{\text {Intra }}^{2}$ to $\mathrm{S}_{\text {Inter }}^{2}$ ) are applicated (Harris 
1974). Accordingly, a reference interval may be useful if the degree of individuality is above 1.4 , whereas the reference interval may be relative insensitive to potentially important changes in the parameter if the degree of individuality is below 1.4, and in particular below 0.6 . In the present study, the degree of individuality is 0.4 for $\mathrm{RBC}, 0.4$ for $\mathrm{WBC}, 0.3$ for $\mathrm{Hb}$, and 0.8 for $\mathrm{PCV}$, thereby indicating that the reference intervals for these parameters may be relative insensitive to potentially important changes. For the haematological parameters of this study, analytical results outside a cows own reference interval could be identified using the critical differences calculated in the present study, since the critical difference may help to judge whether the difference between two consecutive analytical results with a certain probability $(95 \%)$ may be ascribed to natural variation or not. Meanwhile, it could be argued that the critical differences calculated in this study are not directly applicable to diseased cows as the calculations are based on clinically healthy cows. No definite answer to this point can be obtained from the present study, but it has been reported in human medicine that in nonacute pathological processes, where new homeostatic steadystates are reached, biological variation around the new mean values are of the same magnitude as in healthy persons (Fraser \& Hearne 1982, Pascoe et al. 1984). However, other reports have indicated that the intra-individual variation is greater in patients with chronic diseases compared to healthy persons (Hölzel 1987A, 1987B, 1987C). Evidently, there may be a problem when the first measurement as well as the second may be affected by the disease status of the cow. Further, when a cow is presented for the first time for diagnosis, the only way the analytical result can be interpreted is by comparison with appropriate population- based reference intervals. Therefore, the most appropriate use of the critical difference seems to be in conjunction with the corresponding reference intervals.

As in earlier studies (Jensen et al. 1992), the total variance on the analytical results was divided into $\mathrm{S}_{\text {Inter, }}, \mathrm{S}_{\text {Intra }}^{2}$, and $\mathrm{S}^{2}$ Anal (Table $1)$, and the critical differences were then calculated from $\mathrm{S}_{\text {Intra }}$ and $\mathrm{S}^{2}$ Anal. The components of variance for PCV (Table 1) are quite small compared to those of the other parameters. The PCV values are, however, smaller (reference interval 0.28 - 0.42) compared to the other parameters, for which reason the components of variance for PCV will also be smaller compared to the other parameters. In the calculation of the critical differences, the component of variance due to other factors $\left(\mathrm{S}^{2}\right.$ Others $)$ was left out of account. It could be argued that $S^{2}$ Others could contribute considerably to the total variance due to the diurnal variations of the bovine haematological parameters (Abt et al. 1966). However, the blood samples were collected at the same time each day, thereby minimizing the variance due to diurnal variations. It could also be argued that the analytical between-day variance could contribute considerably to the total variance. However, reliable haematological results can only be obtained if the blood is analysed within a few $h$ after collection (Jain 1986). Therefore, haematological parameters were analysed in the same run at the same day as the blood samples were obtained. Further, analysing the parameters in different runs more closely resembles the conditions in practice.

Another source of error, which was not investigated in this study, could be the different lactation stages of the cows, which might be responsible for a part of the variation between cows and also for the different magnitudes of the intra-individual variations 
around the mean value of individual cows (Fig. 1). Further, it might also be the reason for some of the cows to have mean values outside the reference intervals (Fig. 1), although it would be expected to observe that some cows had analytical results outside the reference interval since the reference interval only included $95 \%$ of the results from an appropriate reference population.

Altogether, the critical differences calculated in the present study are most likely an underestimation for some cows and an overestimation for other cows, and thus, the critical differences should only serve as guidelines.

In conclusion, the results suggest that the critical differences calculated in the present study may be of value as indicators of potentially important changes in the red blood cell count, the white blood cell count, the haematocrit, and the haemoglobin concentration in cows. However, analytical results of these haematological parameters should not be assessed by the critical difference alone, but should also be compared to the corresponding reference intervals.

\section{Acknowledgements}

The authors wish to acknowledge the financial support of R. Nørtoft Thomsens Legat and to thank Mrs. Annette Pedersen, Internal Medicine and Mrs. Emma Thomsen, Central Laboratory, Department of Clinical Studies, for excellent technical assistance.

\section{References}

Abt DA, Ipsen J, Hare WCD, Marshak RR, Sahl J: Circadian and seasonal variations in the hemogram of mature dairy cattle, Cornell Vet. 1966, $56,479-520$.

Costongs GMPJ, Janson PCW, Bas BM, Hermans J, Van Wersch JWJ, Brombacher PJ: Short-term and long-term intra-individual variations and critical differences of clinical chemical laboratory parameters. J. clin. Chem. clin. Biochem. 1985, 23, 7-16.
Fraser CG, Hearne CR: Components of variance of some plasma constituents in patients with myocardial infarction. Ann. Clin. Biochem. 1982, 19, 431-434.

Harris EK: Effects of intra- and interindividual variation on the appropriate use of normal ranges. Clin. Chem. 1974, 20, 1535-1542.

Hölzel, WGE: Intra-individual variation of some analytes in serum from patients with insulindependent Diabetes mellitus. Clin. Chem. 1987A, 33, 57-61

Hölzel, WGE: Intra-individual variation of some analytes in serum from patients with chronic renal failure. Clin. Chem. 1987B, 33, 670-673

Hölzel, WGE: Intra-individual variation of some analytes in serum from patients with chronic liver diseases. Clin. Chem. 1987C, 33, 1133-1136

Jain NC: Hematologic Techniques. In: Jain NC. (Ed): Schalm's Veterinary Hematology 4th. ed., Lea \& Fibiger, Philadelphia 1986, p. 21-86.

Jensen AL, Houe H, Nielsen CG: Critical differences of clinical chemical parameters in blood from Red Danish Dairy cows. Res. vet. Sci. 1992, 52, 86-89.

Pascoe PJ, Gallagher CS, Fraser CG: Components of biological variation of some serum analytes in hospitalized pregnant women. Clin. Chem. 1984, 30, 583-584.

Snedecor GW, Cochran WG: Statistical Methods 6th. ed., Iowa State University Press, Ames, Iowa 1967, p. 258-298.

Stamm D: A new concept for quality control of clinical laboratory investigations in the light of clinical requirements and based on reference method values. J. clin. Chem. clin. Biochem. 1982, $20,817-824$.

\section{Sammendrag \\ Kritisk differens for nogle af kvagets hamatologiske parametre. \\ Formålet med nærværende undersøgelse var at beregne den kritiske differens mellem to analytiske resultater for erythrocyttallet (RBC), det totale leukocyttal (WBC), hæmoglobinindholdet (Hb) og hæmatokrit (PCV) hos kvæg. Ved bestemmelse af den kritiske differens bliver det muligt med rimelig sikkerhed at afgøre, om en ændring af den målte parameters værdi enten kan skyldes rene tilfældig- heder eller ej. Der udtoges blodprøver fra 20 lakte- rende kvæg af Rød Dansk Malkerace en gang dag- ligt 5 dage i træk. Ved hjælp af hierarkisk variansa-}


nalyse beregnedes den inter-individuelle, den intraindividuelle og den analytiske variation, og på basis af dette beregnedes den kritiske differens for de analyserede hæmatologiske parametre. I absolutte tal beregnedes den kritiske differens som værende $0,61 \times 10^{12} / 1$ for RBC, $2,2 \times 10^{9} / 1$ for WBC, 0,79 $\mathrm{mmol} / \mathrm{l}$ for $\mathrm{Hb}$ og 0,07 for PCV. De beregnede kritiske differencer $b \varnothing r$ dog kun anvendes som vejledende værdier. Analyseresultater bør derfor ikke bedømmes alene ved hjælp af de beregnede kritiske differenser, men bør også bedømmes i forhold til de respektive reference intervaller.

(Received February 20, 1992; accepted May 22, 1992).

Reprints may be requested from: A. L. Jensen, Department of Clinical Studies, Royal Veterinary and Agricultural University, Bülowsvej 13, DK-1870 Frederiksberg C, Denmark. 